\title{
Adipose-tissue and intestinal inflammation - visceral obesity and creeping fat
}

\section{Lea I. Kredel and Britta Siegmund*}

Gastroenterology, Rheumatology, Infectious Diseases, Medical Department I, Charité - Universitätsmedizin Berlin, Berlin, Germany

\section{Edited by:}

Giamila Fantuzzi, University of Illinois at Chicago, USA

\section{Reviewed by:}

Raja Fayad, University of South

Carolina, USA

Andreas Schaeffler, University

Hospital of Giessen and Marburg,

Germany

\section{*Correspondence:}

Britta Siegmund, Gastroenterology,

Rheumatology, Infectious Diseases,

Medical Department I, Campus

Benjamin Franklin,

Charité - Universitätsmedizin Berlin,

Hindenburgdamm 30, Berlin 12200,

Germany

e-mail: britta.siegmund@charite.de
Obesity has become one of the main threats to health worldwide and therefore gained increasing clinical and economic significance as well as scientific attention. General adipose-tissue accumulation in obesity is associated with systemically increased proinflammatory mediators and humoral and cellular changes within this compartment. These adipose-tissue changes and their systemic consequences led to the concept of obesity as a chronic inflammatory state. A pathognomonic feature of Crohn's disease (CD) is creeping fat (CF), a locally restricted hyperplasia of the mesenteric fat adjacent to the inflamed segments of the intestine. The precise role of this adipose-tissue and its mediators remains controversial, and ongoing work will have to define whether this compartment is protecting from or contributing to disease activity. This review aims to outline specific cellular changes within the adipose-tissue, occurring in either obesity or CF. Hence the potential impact of adipocytes and resident immune cells from the innate and adaptive immune system will be discussed for both diseases. The second part focuses on the impact of generalized adipose-tissue accumulation in obesity, respectively on the locally restricted form in $C D$, on intestinal inflammation and on the closely related integrity of the mucosal barrier.

Keywords: adipose-tissue, intestinal inflammation, Crohn's disease, obesity, adipose-tissue inflammation

\section{INTRODUCTION}

Obesity has become one of the main threats to health worldwide and is outpacing smoking as the primary health hazard (1-4). Due to the increasing clinical and economic significance, fat-tissue has attracted growing scientific attention. Once only recognized as storage for energy, today adipose-tissue is acknowledged as an endocrine organ with multiple functions $(5,6)$.

The extent of the fat storage is inter individually highly variable and ranges from 5 to $60 \%$ of the total body weight. Adipose-tissue is divided into subcutaneous and visceral fat (7).

Several studies reported morphological and functional differences between these adipose-tissue compartments. At least in parts the depot-difference between visceral and subcutaneous fat can be explained by a distinct expression of developmental genes and different adipocyte progenitor cells (8-10). Characteristics of both fat depots are summarized in Table $\mathbf{1}$.

In obesity, a significant expansion of the entire fat-tissue takes place with distinct alterations within the cellular, humoral, and stromal compartment (11-13). The production of proinflammatory mediators and the immune-cell infiltration is increased in adipose-tissue of obese compared to lean individuals $(5,6)$. These adipose-tissue changes and their systemic consequences led to the concept of obesity as a chronic inflammatory state (14). The chronic inflammation results in secondary diseases in the long run and impacts the progression of other illnesses. Especially, visceral adiposity is associated with the development of insulin resistance and correlates strongly with metabolic syndrome (15-17).

Fat accumulation can also be locally restricted. A body weight-independent characteristic hyperplasia of the mesenteric fat-tissue frequently occurs in Crohn's disease (CD). This so-called creeping fat $(\mathrm{CF})$ enwraps the inflamed segments of the gut and covers more than $50 \%$ of the intestinal circumference. Connecting fat accumulation and inflammatory activity, CF correlates with transmural inflammation, fibrosis, muscular hypertrophy, and stricture formation (18-20). Humoral and cellular alterations within the CF are unique and differ from those observed in hypertrophied fat-tissues in obesity (20-22) (Figure 1).

While the existence of CF has been described at the beginning of the last century, the cause of this phenomenon is still unclear.

There is increasing data pointing to a connection between bacterial translocation and the development of CF. Even in the healthy gut bacterial translocation occurs $(23,24)$, but it is strongly increased in $\operatorname{CD}(19,25)$. Bacteria can trigger adipocytes and preadipocytes proliferation in vitro (26). Thus one might speculate, which aggrandized bacterial translocation leads to adiposetissue hyperplasia in $\operatorname{CD}(19,25)$. Recently, nucleotide-binding oligomerization domain (NOD) variations have been shown to influence adipocyte differentiation. Interestingly, NOD2 variants, which are associated with a higher susceptibility to $\mathrm{CD}$, affect bacterial translocation (27). In CD patients, bacterial mRNA is increased in patients carrying bacterial mRNA compared to controls and the amount of bacterial DNA is related to disease activity. Unfortunately, the author of the study did not give any information regarding the mesenteric fat of these patients. Nevertheless bacteria passing though the intestinal barrier are likely to end up in the mesenteric fat close by, where they might trigger CF development (28).

While the connection between obesity, metabolic, and vascular diseases has been studied intensively, the link between 
Table 1 | Adipose tissue depots.

\begin{tabular}{|c|c|c|}
\hline & Subcutaneous adipose tissue (SAT) & Visceral adipose tissue (VAT) \\
\hline $\begin{array}{l}\text { Percentage of the total body } \\
\text { fat }(7,142)\end{array}$ & $\sim 80 \%$ & $\begin{array}{l}\text { or } 10-20 \% \\
\text { o } 5-10 \% \\
\text { The absolute amount of VAT increases with age in both genders }\end{array}$ \\
\hline Main depots (7) & $\begin{array}{l}\text { - Abdominal } \\
\text { - Gluteal } \\
\text { - Femoral }\end{array}$ & $\begin{array}{l}\text { Retro-peritoneal } \\
\text { Intra-peritoneal (omental; mesenteric; epiploic) }\end{array}$ \\
\hline Venous drainage & Dependent on anatomical location & Portal vein \\
\hline $\begin{array}{l}\text { Morphological and functional } \\
\text { characteristics }(7,9,142-151)\end{array}$ & $\begin{array}{l}\text { - Consists of more preadipocytes per (gram) tissue } \\
\text { - Higher expression of leptin and CXCL-10 }\end{array}$ & $\begin{array}{l}\text { - Higher vascularization } \\
\text { - Greater immune-cell content } \\
\text { - Adipocytes have an increased metabolic (both lipogenesis and } \\
\text { lipolysis) activity } \\
\text { - Higher expression of pro-inflammatory cytokines (IL-6, IL-8, } \\
\text { MCP-1, RANTES, MIP-1 } \alpha \text {, and PAI-1) } \\
\text { - Higher adiponectin expression } \\
\text { - Higher expression of molecules from innate immunity, acute } \\
\text { phase response and complement factors, angiotensinogen, and } \\
\text { Plasminogen activator inhibitors-1 } \\
\text { - Omentin expression }\end{array}$ \\
\hline $\begin{array}{l}\text { Metabolic implications }(9, \\
144,147,152,153)\end{array}$ & $\begin{array}{l}\text { - Adipocytes have a higher insulin sensitivity } \\
\text { - Higher adipogenic ability of the stem cell } \\
\text { compartment } \\
\text { - Higher intake capacity for free fatty acids and } \\
\text { triglycerides } \\
\text { - Major metabolic buffer until a certain "tipping } \\
\text { point" } \rightarrow \text { SAT becomes disfunctional due to a } \\
\text { positive caloric balance with adipocyte } \\
\text { hypertrophy, decreased adipogenesis, and } \\
\text { angiogenesis }\end{array}$ & $\begin{array}{l}\text { - Increase is associated with insulin resistance and metabolic } \\
\text { syndrome } \\
\text { - Adipose tissue stem cells over express CD105, Fgf2, and notch } \\
\text { target genes } \\
\text { - Surgical removal of VAT in rodents improves insulin sensitivity } \\
\text { - Diet and exercise cause preferential fat loss from VAT than SAT }\end{array}$ \\
\hline
\end{tabular}

fat accumulation and intestinal inflammation is relatively new. This review aims to examine the association between (intestinal) inflammation and fat accumulation in general and as a local phenomenon. While adipocyte hypertrophy/hyperplasia is accompanied by humoral and cellular changes within the tissue, we particularly discuss the cellular compartments including adipocytes and resident/infiltrating immune cells to define the characteristics of CF versus fat-tissue in obesity.

\section{ALTERATIONS OF FAT-TISSUE COMPOSITION IN OBESITY AND CROHN'S DISEASE \\ ADIPOCYTES}

Adipocytes are divided into brown, beige, and white cells presumably covering diverse intermediate forms. White fat cells represent the main type in adipose-tissues of adults $(29,30)$ therefore this review will focus in this part. Mature white adipocytes contain a large internal fat droplet marginalizing the remaining cytoplasm and nucleus. Adipocytes store the body's energy supplies, actively produce various mediators and are characterized by their cellular plasticity (31).

Remarkably, the absolute adipocyte number seems to be genetically determined and does not change significantly after the end of the growth phase (32). Tissue enlargement in obesity is primarily due to cellular hypertrophy, rarely to hyperplasia. Enlarged adipocytes in obesity have altered secretory activity with high production of pro-inflammatory cytokines and leptin. Additionally their triglyceride storage is increased $(33,34)$.

In contrast, CF is a result of adipose-tissue hyperplasia; the adipocytes are significantly smaller and their number is four times increased compared to normal mesenteric fat-tissue (18). While the morphologic changes take place in the adipose-tissue adjacent to the inflamed intestine, the gene expression profile is even altered in visceral fat distant from the inflamed intestinal segment. In obesity especially pro-inflammatory genes are up-regulated, whereas, visceral adipocytes of CD patients show characteristic patterns of increased pro- and anti-inflammatory gene expression (35). In line with this, smaller adipocytes produce less pro-inflammatory mediators (33) and, once activated, adipocytes from the CF are less responsive toward further stimulation $(36,37)$. Nevertheless, they are highly active producers of different mediators, with significant over-expression of leptin, adiponectin, and resistin as well as of different cytokines and chemokines $(22,38)$ (Figure 1).

Limiting translation from animal models of intestinal inflammation to human disease, none of the available models show 


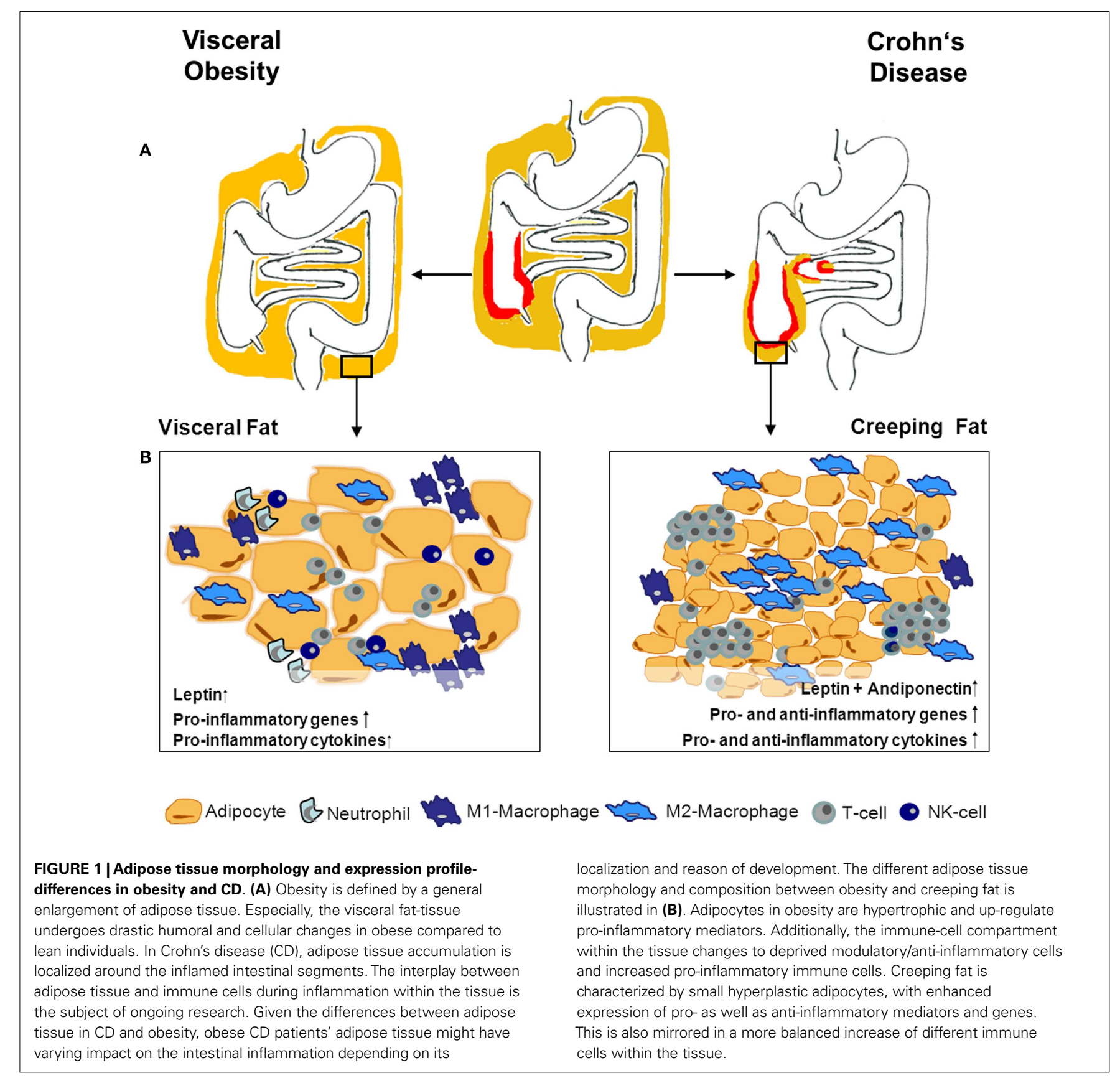

CF-tissue. Still some interesting observation have been made: even though adipose-tissue accumulation does not occur, mononuclear cells infiltrate the mesenteric fat-tissue, adipocyte size decreases, and fibrotic structures appear adjacent to the inflamed murine intestine during acute colitis. Furthermore, mRNA expression of tumor necrosis factor (TNF) $\alpha$, interleukin (IL)-1 $\beta$, and IL-6 are up-regulated (39). In trinitrobenzenesulfonic acid-induced colitis in mice and rats TNF $\alpha$ and IL-10 in the mesenteric fat is increased while leptin and adiponectin release is not altered compared to healthy animals $(40,41)$. Experimental colitis by dinitrobenzenesulfonic acid in Balb/c mice Olivier et al. aimed to establish a model for CF. They successfully induces adipose-tissue accumulation surrounding the ulcerated areas of the inflamed colon (32). This fat accumulation correlated with inflammatory activity and was strictly limited to severe colitis. In contrast to $\mathrm{CD}$ patients, animals with less inflammation or regression of their colitis did not show any signs of CF. The hypertrophic mesenteric fat in mice showed high concentrations of IL-6 and monocyte chemotactic protein (MCP)1 but low adiponectin and leptin levels. Since locally elevated adipokine concentrations are considered hallmarks for the CF, also this model does not completely reflect the distinct characteristics of human CF (42). More recently was shown that in moderately active colitis induced by dinitrobenzenesulfonic 
Table 2 | Immune-cell characterization in obesity versus Crohn's disease.

\begin{tabular}{|c|c|c|c|}
\hline \multirow[t]{2}{*}{ Immune cells } & \multicolumn{2}{|r|}{ Obesity } & \multirow{2}{*}{ 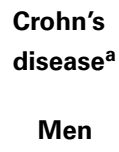 } \\
\hline & Rodents & Men & \\
\hline \multicolumn{4}{|l|}{ Macrophages } \\
\hline$-\mathrm{M} 1$ & $\uparrow \uparrow$ & $\uparrow$ In crown-like structures & $\uparrow$ \\
\hline$-\mathrm{M} 2$ & $\downarrow$ & $\uparrow \uparrow$ & $\uparrow \uparrow$ \\
\hline \multicolumn{4}{|l|}{ Granulocytes } \\
\hline - Eosinophil & $\downarrow$ & n.d. & n.d. \\
\hline - Neutrophil & $\uparrow$ & n.d. & n.d. \\
\hline \multicolumn{4}{|l|}{ ILC } \\
\hline$-N K$ & n.d. & $\uparrow$ In activated CD56 bright & n.d. \\
\hline$-\operatorname{ILC} 2$ & $\downarrow$ & n.d. & n.d. \\
\hline T cells & $\uparrow$ & $\uparrow$ & $\uparrow$ \\
\hline - NKT & $\downarrow$ & $\downarrow$ & n.d. \\
\hline$-\mathrm{CD} 4^{+}$Th1 & $\uparrow$ & $\uparrow$ & n.d. \\
\hline$-\mathrm{CD} 4^{+}$Th2 & $\downarrow$ & n.d. & n.d. \\
\hline$-\mathrm{CD}^{+}$Th17 & $\downarrow$ & n.d. & n.d. \\
\hline$-\mathrm{CD}^{+}$ & $\uparrow$ & n.d. & n.d. \\
\hline - Regulatory FoxP3 ${ }^{+}$ & $\downarrow$ & $\downarrow / \uparrow$ & n.d. \\
\hline
\end{tabular}

a No "Rodents" column due to missing immune cells in mesenteric fat-tissue of animal models for Crohn's disease.

n.d., To our best knowledge not done yet.

acid or dextran sodium sulfate reduced mesenteric fat-tissue was accompanied by increased IL- 6 and MCP- 1 but decreased adiponectin expression (43).

Besides adipocytes, preadipocytes, stroma cells, and various immune cells are found within the adipose-tissue. Cells of the innate and of the adaptive immune system infiltrate this compartment and their composition changes dependent of the body constitution (44) (Table 2). We again focus on the most relevant cell populations for obesity and CD.

\section{ADIPOSE-TISSUE MACROPHAGES}

Macrophages are a heterogeneous cell population, roughly divided into the classically activated, pro-inflammatory M1 and the alternatively activated, immune modulatory M2 subtype, representing two ends of a broad spectrum of plasticity $(45,46)$. Tissueresident macrophages are strongly influenced by their environment $(47,48)$.

Murine adipose-tissue macrophages (ATM) are characterized by high CD14, IL-10, and arginase 1 expression (49). In humans, a broad receptor-expression including the mannose receptor (CD206), various scavenger receptors as well as adhesion molecules like CD163, $\alpha$ v $\beta 5$ integrin, CD209, CD200, CD1b, and CD1c has been described for ATM. These macrophages showed high scavenger activity and significant IL-10 and IL-1 receptor antagonist production. In contrast to the "anti-inflammatory" phenotype of some in vitro-polarized M2-macrophages, ATM produce large amounts of pro-inflammatory cytokines including TNF $\alpha$ in response to stimulation with either Toll-like receptor ligands or interferon- $\gamma(50,51)$. In summary, ATM show an M2 phenotype with pro-inflammatory properties $(50,51)$.

In obesity and in $\mathrm{CD}$, macrophages accumulate in adiposetissues. The accumulation within the fat represents an early event in obesity in mice and men (52-54). ATM are a major source of pro-inflammatory mediators in obesity and contribute significantly to the systemic inflammatory status $(12,55-58)$. ATM can inhibit the effect of insulin in adipocytes leading to systemic insulin resistance via endocrine signaling (54,59-62). Hence ATM strongly contribute to inflammatory as well as to metabolic consequences of obesity.

Lymphocyte antigen (Ly) $6 \mathrm{C}^{\text {high }}$ monocytes in the circulation (comparable to $\mathrm{CD} 14^{+}$cells in humans) are rapidly recruited to inflammatory sites and sites of tissue remodeling (47). They give rise to monocyte-derived macrophages and dendritic cells. Withal tissue-resident macrophages have to be distinguished from freshly recruited monocytes that differentiate depending on the local milieu (47). Which factors recruit cells into the adipose-tissue and direct polarization of monocytes into their various subsets is not fully understood yet. But ATM accumulation is clearly associated with increased chemokine and adipokine production within the adipose-tissue $(63,64)$. Especially, MCP-1/CCL2 recruits macrophages into this compartment contributing to insulin resistance (63). Pointing to additional mediators/mechanisms for ATM recruitment, CC-motif receptor (CCR)2-deficiency does not suffice to reduce ATM number and insulin resistance in obese mice (64, 65). CCR5 has also been associated with adipose-tissue inflammation and insulin resistance in mice (66). CXC-motif ligand (CXCL) 12, which is increased in diet-induced obesity facilitates ATM recruitment. Blocking the corresponding receptor CXC-motif receptor (CXCR) 4 resulted in reduced macrophage accumulation and cytokine release (67). As part of a positive feedback loop between adipose-tissue and bone marrow, adiposetissue-derived mediators like IL- $1 \beta$, induce myeloproliferation and monocyte development, contributing to the macrophage accumulation (68). Also hypoxia due to cell hypertrophy takes part in macrophage infiltration in obesity $(69,70)$. Recently, local proliferation of macrophages within the fat was discovered (71-73). Since only a subset proliferates (74), this does not seem to be the main source of ATM accumulation (73).

It has been known for a while that diet-induced obesity gives rise to a phenotype switch from M2 dominance to that of M1 macrophages in the visceral adipose-tissue of obese mice (49). These macrophages express the M1 markers IL-6, CD11c along with the inducible NO synthase (iNOS) and are typically arranged in crown-like structures around necrotic adipocytes $(49,75,76)$.

Human studies regarding ATM alterations in obesity provide contradicting results. On one hand ATM from subcutaneous fat-tissue of obese subjects produce pro-inflammatory markers $(57,77)$ regressing with weight loss $(57,77,78)$. On the other hand M2c-like macrophages with high fibrotic activity and CD150 expression outnumber M1 macrophages forming crownlike structures in the subcutaneous fat of obese patients (79). Correspondingly, ATM from the subcutaneous fat of obese patients were recently found to highly express the anti-inflammatory markers CD163 and IL-10, while TNF $\alpha$ and IL-6 were reduced compared to lean individuals. Since pro-inflammatory markers were 
equally enhanced, the authors concluded that the adipose-tissue of obese subjects remains more inflamed than in lean subjects (80).

Comparing subcutaneous and visceral fat-tissue, a minor subgroup of ATM localizes within the crown-like structures and the majority appears randomly distributed within the tissues (81). Macrophages in crown-like structures are $\mathrm{CD}_{206}{ }^{+} \mathrm{CD} 11 \mathrm{c}^{+}$and show features of both subgroups. The other ATM are CD206 ${ }^{+}$, $\mathrm{CD}_{3}{ }^{+}$and positive for multiple scavenger receptors but do not express CD11c suggesting their involvement in tissue repair and maintenance. Remarkably, only the amount of CD11c ${ }^{+}$cells correlated with insulin resistance (81).

A distinct macrophage accumulation is also characteristic for the CF. Although iNOS $^{+}$M1 macrophages are increased, a far greater accumulation of $\mathrm{CD}_{163}{ }^{+}$and stabilin $1^{+} \mathrm{M} 2$ macrophages suggests a domination of these cells in the CF (82). Specific functions of this cell population are not known so far but in vitro data suggest that resident macrophages are strongly influenced by locally increased adipokine levels. Leptin and adiponectin might favor the M2 subtype with high secretory activity for pro- and anti-inflammatory chemokines and cytokines within the CF $(82,83)$.

\section{GRANULOCYTES}

While macrophages are by far the best characterized immune cells in adipose-tissues, eosinophil granulocytes recently have gained attention. In lean mice, they represent around 5\% of the adipose-tissue cells, with decreasing percentages in obesity (84). Eosinophils have been found to substantially modulate adipose-tissue inflammation. Being potent producers of IL-4 and IL-13, they support M2-macrophage polarization and thereby impact glucose homeostasis $(84,85)$. In obese mice, numbers of eosinophils and M2-macrophages are dramatically reduced within the adipose-tissue. Accordingly, eosinophil-deficient mice have been characterized by high body-fat percentages and metabolic deficiencies like impaired glucose tolerance (84). Eosinophils seem to affect beige progenitors adipocytes and are involved in adaptation of WAT depots to thermogenic challenges (86). However, their recruitment into the fat and their specific function has yet to be elucidated (86). To our knowledge, neither the distribution of eosinophils in adipose-tissues of obese individuals nor in the CF has been studied yet.

Neutrophil granulocytes are rarely found in visceral fat of lean mice but are rapidly recruited into the visceral fat in obesity and seem to take part in impaired insulin sensitivity (87). With neutrophil recruitment as a fast acute response in inflammatory processes in general and the neutrophil chemoattractant IL-8 produced by activated adipocytes and polarized macrophages, recruiting neutrophils is likely to be part of the adipose-tissue inflammation in humans $(82,87)$. Again, their specific impact in human adipose-tissue inflammation and the generation of CF is not known so far.

\section{INNATE LYMPHOID CELLS}

Innate lymphoid cells (ILC), cells from the lymphoid line lacking antigen specificity, represent a recently described cell population within the adipose-tissue $(88,89)$. They are currently classified based on their cytokine expression and specific transcription factors (90). The first group is innate effectors cells with cytotoxic activity comprising natural-killer (NK) and ILC1 cells (91). ILC2, also called natural helper cells, are defined by their production of type- 2 cytokines such as IL-4, IL-5, and IL-13 and by the transcription factor GATA3 (92-94). The third group includes ILC3 and lymphoid-tissue inducer (LTi) cells. ILC3 express the NK-cell-activating receptor 46 and ROR $\gamma$ t. In contrast to ILC1 cells they do not produce cytotoxic mediators. This subgroup is mainly found in the mucosa of the intestine. ILC3 as well as LTi have been shown to produce IL-17A and IL-22 $(91,94)$.

Especially, ILC2 cells seem to be critical in adipose-tissue homeostasis (84). By producing IL-5 and IL-13 they recruit eosinophils and M2-macrophages into adipose-tissues (89). Interestingly, IL25 treatment increased the numbers of ILC 2 cells in adipose-tissue of obese mice leading to weight loss and improved glucose tolerance (88). Data on ILC2 in human adipose-tissue are lacking at this point.

A little more is known about NK-cells in fat. NK-cells are categorized according to the intensity of CD56 expression. CD56 bright cells are predisposed for IFN $\gamma$ production and express tissuehoming receptors, whereas, CD56 ${ }^{\mathrm{dim}}$ cells are present in the peripheral blood and mediate cytotoxicity $(95,96)$. While numbers of circulating NK-cells are altered in obesity, the number of resident cells in fat-tissues does not change (97). However, the proportion of CD56 $6^{\text {bright }}$ cells within the total NK-cell population seems to be increased in obese subjects and to highly express the activating receptor NKG2D. This activated NK phenotype might indicate their significance for adipose-tissue inflammation that requires further investigation (98).

\section{T CELL COMPARTMENT}

\section{Natural-killer T cells}

From their innate siblings to the adaptive equivalent: naturalkiller T (NKT) cells represent a link between innate and adaptive immunity. Lynch recently provided a detailed overview about their significance in human and murine adipose-tissue (99). NKT cells are divided into type I and type II NKT cells. The well characterized type I NKT cells, also called invariant NKT (iNKT) cells are present in healthy human and murine adipose-tissue. They recognize lipid antigens independent of MHC II via CD1d-restricted presentation by antigen-presenting cells. Upon activation, iNKT cells are fast and potent producers of different chemokines that due to their strong cytotoxic impact activate other immune cells and contribute to anti-tumor activity (99). iNKT cells are primarily tissue-resident cells and comprise T-helper (Th)1-, Th2-, and Th17-like iNKT subsets, whose phenotype and function depends on the local milieu $(100,101)$. Most adipose-tissue iNKT are $\mathrm{CD}^{-}, \mathrm{NK} 1.1^{-}$, and Th2-polarized cells with regulatory potential and high IL-10 expression $(102,103)$.

Obesity leads to a decrease of adipose-tissue iNKT in humans and rodents that normally protect from diet-induced obesity and secondary diseases (102-106). By producing regulatory cytokines, enhancing anti-inflammatory macrophages and affecting adipocyte function iNKT cells induce weight loss, and improve fatty liver disease and insulin resistance (105). NKT cell-deficient mice are more susceptible to health risks associated with high-fat 
diet (HFD) as indicated a fast increase in weight and reduced physical activity (107).

The role of type II NKT cells in adipose-tissue and in obesityrelated diseases is less well defined. Even though $\mathrm{CD}_{1} \mathrm{~d}^{-1-}$ mice lacking both NKT populations gain weight and develop metabolic problems, it has been suggested that type II NKT cells are involved in the induction of adipose-tissue inflammation $(88,89)$. Treatment with IL-25 known to induce ILC2 expansion, resulted in increased infiltration of iNKT and type II NKT cells as well as of other immune cells within the adipose-tissue of obese mice. These cellular changes were accompanied by weight loss and improved glucose tolerance (88). While studies emphasize a protective function for NKT cells regarding obesity and its metabolic consequences, the ultimate proof remains to be provided.

\section{T-helper cells}

In lean individuals about $10 \%$ of the cellular compartment of adipose-tissue consists of $\mathrm{CD}^{+}$lymphocytes, predominantly of $\mathrm{CD} 4{ }^{+} \mathrm{Th} 2$ or $\mathrm{CD} 4{ }^{+} \mathrm{CD} 25^{+}$forkhead box protein $3^{+}$regulatory $\mathrm{T}$ cells (Treg) (108). However, in obese mice the ratio of $\mathrm{CD}^{+}$and $\mathrm{CD}^{+}{ }^{+} \mathrm{T}$ cells is shifted toward $\mathrm{CD} 8^{+}$cytotoxic T cells. Within the $\mathrm{CD}^{+}{ }^{+}$lineage $\mathrm{Th} 17$ cells as well as Treg are profoundly reduced resulting in a dominance of Th1 cells in this compartment. Supporting this, the absolute cell numbers of Th1 cells are about threefold higher in the visceral fat of diet-induced obese mice as compared to lean controls (108).

In obese humans, the overall number of adipose-tissue $\mathrm{T}$ cells is increased (109-111), with a dominance of Th1 over Treg. The ratio correlates with the body mass index (BMI) and changes from 6:1 in lean to 12:1 in obese individuals (112). A positive correlation between the $\mathrm{T}$ cell count in adipose-tissue and the BMI of diabetes patients suggests an involvement of these cells in obesity-related metabolic diseases $(13,14)$.

\section{Regulatory T cells}

The impact of adipose-tissue Treg has been studied intensively. In lean individuals, Treg accumulate in VF but not in SF (108, 113). Compared to Treg from other organs adipose-tissue Treg have a distinct $\mathrm{GATA}^{+}{ }^{+}, \mathrm{CCR} 2^{+}, \mathrm{KLRG}^{+}$, and $\mathrm{CD} 103^{-}$phenotype with over-expression of CCR1, CCR2, CCR3, CCR5, CCR9, CXCR6, and down-regulation of CCR6, CCR7, CXCR3 (108, 113). Repeated $\mathrm{T}$ cell receptor clones are highly suggestive for an adipose-tissue-specific antigen. Besides chemotaxis, e.g., receptor equipment, adipokines, and macrophage-derived mediators seem to contribute to Treg accumulation in the visceral adipose-tissue $(108,113,114)$. From a mechanistic point of view, the peroxisome proliferator-activated receptor PPAR $\gamma$ represents a central regulatory pathway for Treg infiltration into the visceral fat (115).

In healthy lean individuals, approximately $15 \%$ of the $\mathrm{CD} 4^{+} \mathrm{T}$ cells are Treg; in some inflammatory conditions or malignancies this proportion can increase up to $40 \%(108,113,114)$. In contrast, as shown in several animal models obesity is accompanied by a pronounced decline of adipose-tissue Treg. The chemokine receptor-expression is altered in adipose-tissue Treg of obese mice with down-regulated CCR1, CCR2, and CXCR6 but increased CXCR3 expression (114). Loss of Treg was associated with higher insulin resistance and risk for diabetes mellitus in these animals
$(11,108,116,117)$. Interestingly, aging per se seems to reduce the numbers of adipose-tissue Treg paralleled by an increased risk for insulin resistance even in lean mice (114). The anti-diabetic $\operatorname{PPAR} \gamma$ agonist pioglitazone increases the Treg numbers in the visceral fat of lean and obese mice (116) underlining that current anti-diabetic treatment directly relies on Treg control (114).

While murine adipose-tissue Treg have been analyzed in detail, little is known about their human counterparts and the results are somewhat conflicting. Three studies found a BMI-dependent decrease of $\mathrm{CD}^{+}{ }^{+} \mathrm{FoxP}^{+}{ }^{+}$adipose-tissue Treg in the visceral fat of obese humans $(11,108,112)$. Zeyda et al. detected higher FoxP3 expression in the same location (118). Treg are involved in gut homeostasis, mucosal integrity, and tolerance (119). While the frequency of Treg in the peripheral blood of patients with inflammatory bowel diseases (IBD) is low, their number is increased within the inflamed mucosa $(120,121)$. To our knowledge Treg within the adjacent CF have not been quantified yet. With respect to their significance in visceral fat as well as their potential role in IBD further studies regarding this subject are required. Of special interest is that IL-6 can convert Treg into IL-17 producing cells (122) - two cytokines suggested to play a dominant role in the pathogenesis of IBD (123).

To sum up, adipose-tissue hypertrophy is accompanied by profound changes within the resident immune-cell compartment, leading from homeostasis toward a pro-inflammatory local environment. In obesity, these changes have been associated with systemic inflammation and contribute to insulin resistance and type2 diabetes $(49,75,87,102-104,108,112)$. Thus, the inflammatory status of adipose-tissue depends on different factors including location and composition of immune-cell compartments. The last one is strongly influenced by weight gain and obesity resulting in a shift from a homeostatic regulatory environment comprising M2macrophages, eosinophil granulocytes, NKT cells, and CD4 ${ }^{+}$Treg toward a more pro-inflammatory environment characterized by a dominance of M1 macrophages and a T cell compartment altered toward $\mathrm{CD}^{+}{ }^{+} \mathrm{Th} 1$ and $\mathrm{CD}^{+}$cytotoxic subtypes. How these changes are initiated and which individuals are mainly affected remains to be explored.

Having summarized, the current knowledge of the cellular compartment within the adipose-tissue, the last section of this review will serve to outline the interplay of the intestine and the mesenteric fat-tissue.

\section{OBESITY AND BARRIER DEFECT}

The mucosal barrier consisting of the different cells within the epithelia layer and lamina propria, including (resident) immune cells as well as their cellular products (e.g., mucus, defensins, and cytokines), allows for the absorption of nutritional factors but prevent from increased translocation of bacteria and viruses. Obesity alone seems to suffice to induce an impaired barrier function and intestinal inflammation in rodents (124-126). HFD facilitates translocation of intestinal bacteria and thereby triggers low-grade inflammation in obesity. Emphasizing that the intestinal microbiota forms a prerequisite for the effect of HFD, induced TNF $\alpha$ mRNA and nuclear factor- $\kappa \mathrm{B}$ activation was only found in the intestine of specific pathogen free but not of germfree mice (113). In line with these observations, ileal TNF $\alpha$ mRNA expression 
correlated to weight gain, obesity, and insulin resistance in mice (124). HFD not only affect the microbiota composition in mice with reduced Lactobacillus and increased Oscillibacter species but equally results in elevated intestinal permeability due to alterations in tight-junction proteins accompanied by a low transepithelial resistance contributing to the barrier defect. In consequence, the mesenteric fat is infiltrated by large numbers of macrophages and associated up-regulation of pro-inflammatory molecules like IL-6 and TNF $\alpha$ (125). These obesity-driven changes are not restricted to dietary-induced obesity. In two genetically driven obese mouse models mucosal barrier defects were concomitant with the increase of bacterial endotoxin and pro-inflammatory cytokines in the portal blood (126).

Taken together these data suggest that the intestinal barrier influenced by genetic risk factors, microbiota, and nutritional factors exert a substantial impact on the development of adipose-tissue inflammation in obesity.

While in obesity mucosal barrier is only mildly affected, CD is characterized by a transmural inflammation with subsequent destruction of the intestinal barrier.

\section{OBESITY AND CROHN'S DISEASE}

Even though CD patients rather have normal or subnormal BMI, obesity has become an increasing problem even in this patient collective (127). Whether obesity is a risk factor for CD has not been conclusively answered. A study with 524 obese IBD patients of all ages found a slightly higher risk for developing CD but not for ulcerative colitis. The association was strong for older patients where the influence of environmental factors is expected to be more pronounced in general (128). A European prospective cohort study did not associate obesity to an increased risk of developing CD (129).

Once CD has been established, the course of disease is significantly altered by the patient's constitution. Overweight CD patients are more prone to active disease and show more frequent anorectal involvement. Consequently, the hospitalization rate is higher and the time until the first surgery is shorter in overweight CD patients compared to lean individuals (128, 130-132). However, there seems to be no significant difference between the overall number of surgical interventions $(128,132,133)$.

While children with CD typically present with weight loss and growth retardation, a recent study including nearly 1600 children indicates that approximately $20 \%$ of the children with CD were overweight or obese. The rate of obesity in children with ulcerative colitis was $30 \%$ and thus comparable to the general population (134). Different from the adult population obesity, had no significant effect on the short-term clinical outcomes of IBD with any perceived difference in disease severity, short-term complications, emergent admissions, or the need for surgical intervention in children. Nevertheless obesity does increase the risk of urinary tract infections and central venous catheter infection in pediatric IBD patients (135).

Besides the progression of disease, also response to therapy seems to be different when comparing lean and obese CD patients. First evidence has been provided by a small single center study that observed a higher risk for loss of response to adalimumab, but not to infliximab treatment of CD in obese patients. The authors hypothesize that the increased body-fat content impairs the efficiency due to changed pharmacokinetic properties. Additionally, high concentrations of circulating pro-inflammatory molecules also altering the therapeutic effect led to the conclusion, which weight-adjusted anti-TNF therapy should be favored in obese patients (136). Using this approach for infliximab treatment did not overcome the shorter time to loss of response in obese IBD patients compared to lean controls, suggesting that weight-adjusted therapy alone is not sufficient (137); a phenomenon also observed in obese spondyloarthritis patients receiving weight-adjusted infliximab therapy (138).

\section{DIET VERSUS OBESITY - WHAT DRIVES INFLAMMATION?}

As mentioned above, HFD followed by weight gain induces intestinal barrier alterations. Thus not only the events within the fattissue and their systemic impact, but also the factors leading to obesity might directly influence inflammatory processes in CD. Especially western (high-fat) diet affects intestinal inflammation in multiple ways from luminal microbiota composition to antigen presentation and change in prostaglandin balance. In a systematic review, Hou et al. outlined the association between pre-diagnosis dietary intake and the risk of developing IBD (139). A higher risk for ulcerative colitis or CD associates with HFD, the increased intake of polyunsaturated fatty acids, omega- 6 fatty acids, and meats; and also with saturated fatty acids in CD. While high intake of dietary fiber and fruits decreased the risk of developing CD, ulcerative colitis remained unaffected (139).

Data from animal models support these observations. HFD enhanced intestinal inflammation in a mouse model of experimental colitis (140). Particularly palm-oil based HFD fed to $\mathrm{TNF}^{\triangle \mathrm{ARE} / \mathrm{WT}}$ mice did not only aggravate intestinal inflammation but promoted expansion of inflammation into the proximal colon, which seems to be of significance given the increased incidence of colonic disease in obese CD patients (127). In this study, disease severity was not associated with development of obesity or metabolic dysfunction, which led to the conclusion that the increased inflammatory activity might not be related to obesity per se but is rather induced by the diet itself. Gruber et al. emphasized dietary lipids and so-called metabolic endotoxemia as causes for increased intestinal permeability and pro-inflammatory immune-cell responses (140).

A direct impact on microbiological composition with a rise in the proportion of sulfite-reducing pathobiont bacteria (e.g., Bilophila wadsworthia) has been shown for a HFD with mainly saturated fatty acids. These specific bacterial changes were associated with a pro-inflammatory Th1-driven immune response. This diet led to a higher incidence of colitis in genetically susceptible IL- $10^{-1-}$ mice as well as in dextran sulfate sodium -induced colitis. By altering the intraluminal conditions (e.g., host bile acids) saturated fatty acids within the western diet may induce dysbiosis and thereby facilitate an increased inflammatory activity (141).

\section{CONCLUSION}

Adipose-tissue and its resident cells seem to be highly adaptable and functionally depending on location, cellular composition and dissemination. While obesity is characterized by a widespread increase of adipose-tissue hypertrophy, the fat accumulation in 
CD is localized and independent of the body weight. Hypertrophic adipocytes have a pro-inflammatory gene expression profile and produce large amounts of pro-inflammatory mediators. Additionally, resident immune cells within the hypertrophic fat-tissue in obesity are primed toward a more proinflammatory subtype. These adipose-tissue changes have systemic consequences including elevated serum levels of proinflammatory cytokines, C-reactive protein, and leptin. In this way, adipose-tissue inflammation contributes to the development of secondary diseases like diabetes and hypertension in obese individuals.

In contrast secretory adipose-tissue changes in CD seem to be rather focused to the mesenteric fat body. However, a systemic impact can be equally suggested, since C-reactive protein that is found increased systemically in active disease, can be produced by the mesenteric fat-tissue. Interestingly, adipokine levels are only locally elevated. Yet, the gene expression profile as well as mediator secretion of small adipocytes within the CF is characterized by both anti- as well as pro-inflammatory capacities, pointing to a more balanced situation within the fat-tissue. Thus adipose-tissue inflammation in the CF might directly modulate, possible even control, intestinal inflammation.

While there are convincing mouse data to adipose-tissue changes in obesity, human data are still rare. Especially in regard to the differences between mouse and man (e.g., macrophage distribution in adipose-tissue) there is a need for comparative studies. Additional studies are required to characterize resident immune cells within the fat in inflammatory conditions especially in the visceral and CF. While knowledge about alterations in obese individuals might help to reveal novel strategies for the fight against obesity, a better understanding of the role of the adipose-tissue might also help to define novel therapeutic strategies for CD.

\section{REFERENCES}

1. Buchwald H. Consensus conference statement bariatric surgery for morbid obesity: health implications for patients, health professionals, and thirdparty payers. Surg Obes Relat Dis (2005) 1(3):371-81. doi:10.1016/j.soard.2005. 04.002

2. Finucane MM, Stevens GA, Cowan MJ, Danaei G, Lin JK, Paciorek CJ, et al. National, regional, and global trends in body-mass index since 1980: systematic analysis of health examination surveys and epidemiological studies with 960 country-years and 9.1 million participants. Lancet (2012) 377(9765):557-67. doi:10.1016/S0140-6736(10)62037-5

3. Barness LA, Opitz JM, Gilbert-Barness E. Obesity: genetic, molecular, and environmental aspects. Am J Med Genet A (2007) 143A(24):3016-34. doi:10.1002/ ajmg.a.32035

4. Haslam DW, James WP. Obesity. Lancet (2005) 366(9492):1197-209. doi:10. 1016/S0140-6736(05)67483-1

5. Rocha VZ, Libby P. Obesity, inflammation, and atherosclerosis. Nat Rev Cardiol (2009) 6(6):399-409. doi:10.1038/nrcardio.2009.55

6. Gregor MF, Hotamisligil GS. Inflammatory mechanisms in obesity. Annu Rev Immunol (2011) 29:415-45. doi:10.1146/annurev-immunol-031210-101322

7. Lee MJ, Wu Y, Fried SK. Adipose tissue heterogeneity: implication of depot differences in adipose tissue for obesity complications. Mol Aspects Med (2013) 34(1):1-11. doi:10.1016/j.mam.2012.10.001

8. Vohl MC, Sladek R, Robitaille J, Gurd S, Marceau P, Richard D, et al. A survey of genes differentially expressed in subcutaneous and visceral adipose tissue in men. Obes Res (2004) 12(8):1217-22. doi:10.1038/oby.2004.153

9. Tchkonia T, Tchoukalova YD, Giorgadze N, Pirtskhalava T, Karagiannides I, Forse RA, et al. Abundance of two human preadipocyte subtypes with distinct capacities for replication, adipogenesis, and apoptosis varies among fat depots.
Am J Physiol Endocrinol Metab (2005) 288(1):E267-77. doi:10.1152/ajpendo. 00265.2004

10. Gesta S, Bluher M, Yamamoto Y, Norris AW, Berndt J, Kralisch S, et al. Evidence for a role of developmental genes in the origin of obesity and body fat distribution. Proc Natl Acad Sci U S A (2006) 103(17):6676-81. doi:10.1073/pnas.0601752103

11. Deiuliis J, Shah Z, Shah N, Needleman B, Mikami D, Narula V, et al. Visceral adipose inflammation in obesity is associated with critical alterations in tregulatory cell numbers. PLoS One (2011) 6(1):e16376. doi:10.1371/journal.pone. 0016376

12. Fain JN, Madan AK, Hiler ML, Cheema P, Bahouth SW. Comparison of the release of adipokines by adipose tissue, adipose tissue matrix, and adipocytes from visceral and subcutaneous abdominal adipose tissues of obese humans. Endocrinology (2004) 145(5):2273-82. doi:10.1210/en.2003-1336

13. Kintscher U, Hartge M, Hess K, Foryst-Ludwig A, Clemenz M, Wabitsch M, et al. T-lymphocyte infiltration in visceral adipose tissue: a primary event in adipose tissue inflammation and the development of obesity-mediated insulin resistance. Arterioscler Thromb Vasc Biol (2008) 28(7):1304-10. doi:10.1161/ ATVBAHA.108.165100

14. Rocha VZ, Folco EJ. Inflammatory concepts of obesity. Int J Inflam (2011) 2011:529061. doi:10.4061/2011/529061

15. Barbarroja N, Lopez-Pedrera R, Mayas MD, Garcia-Fuentes E, Garrido-Sanchez $\mathrm{L}$, Macias-Gonzalez M, et al. The obese healthy paradox: is inflammation the answer? Biochem J (2010) 430(1):141-9. doi:10.1042/BJ20100285

16. Sam S, Haffner S, Davidson MH, D'Agostino RB Sr, Feinstein S, Kondos G, et al. Relation of abdominal fat depots to systemic markers of inflammation in type 2 diabetes. Diabetes Care (2009) 32(5):932-7. doi:10.2337/dc08- 1856

17. Schaffler A, Muller-Ladner U, Scholmerich J, Buchler C. Role of adipose tissue as an inflammatory organ in human diseases. Endocr Rev (2006) 27(5):449-67. doi:10.1210/er.2005-0022

18. Peyrin-Biroulet L, Chamaillard M, Gonzalez F, Beclin E, Decourcelle C, Antunes $\mathrm{L}$, et al. Mesenteric fat in Crohn's disease: a pathogenetic hallmark or an innocent bystander? Gut (2007) 56(4):577-83. doi:10.1136/gut.2005.082925

19. Sheehan AL, Warren BF, Gear MW, Shepherd NA. Fat-wrapping in Crohn's disease: pathological basis and relevance to surgical practice. Br J Surg (1992) 79(9):955-8. doi:10.1002/bjs.1800790934

20. Fink C, Karagiannides I, Bakirtzi K, Pothoulakis C. Adipose tissue and inflammatory bowel disease pathogenesis. Inflamm Bowel Dis (2012) 18(8):1550-7. doi:10.1002/ibd.22893

21. Drouet M, Dubuquoy L, Desreumaux P, Bertin B. Visceral fat and gut inflammation. Nutrition (2012) 28(2):113-7. doi:10.1016/j.nut.2011.09.009

22. Paul G, Schaffler A, Neumeier M, Furst A, Bataillle F, Buechler C, et al. Profiling adipocytokine secretion from creeping fat in Crohn's disease. Inflamm Bowel Dis (2006) 12(6):471-7. doi:10.1097/00054725-200606000-00005

23. Peyrin-Biroulet L, Gonzalez F, Dubuquoy L, Rousseaux C, Dubuquoy C, Decourcelle $\mathrm{C}$, et al. Mesenteric fat as a source of $\mathrm{C}$ reactive protein and as a target for bacterial translocation in Crohn's disease. Gut (2012) 61(1):78-85. doi:10.1136/gutjnl-2011-300370

24. Batra A, Heimesaat MM, Bereswill S, Fischer A, Glauben R, Kunkel D, et al. Mesenteric fat - control site for bacterial translocation in colitis? Mucosal Immunol (2012) 5(5):580-91. doi:10.1038/mi.2012.33

25. Pond CM. Adipose tissue and the immune system. Prostaglandins Leukot Essent Fatty Acids (2005) 73(1):17-30. doi:10.1016/j.plefa.2005.04.005

26. Zulian A, Cancello R, Ruocco C, Gentilini D, Di Blasio AM, Danelli P, et al. Differences in visceral fat and fat bacterial colonization between ulcerative colitis and Crohn's disease. An in vivo and in vitro study. PLoS One (2013) 8(10):e78495. doi:10.1371/journal.pone.0078495

27. Tanabe T, Chamaillard M, Ogura Y, Zhu L, Qiu S, Masumoto J, et al. Regulatory regions and critical residues of NOD2 involved in muramyl dipeptide recognition. EMBO J (2004) 23(7):1587-97. doi:10.1038/sj.emboj. 7600175

28. Gutierrez A, Scharl M, Sempere L, Holler E, Zapater P, Almenta I, et al. Genetic susceptibility to increased bacterial translocation influences the response to biological therapy in patients with Crohn's disease. Gut (2014) 63(2):272-80. doi:10.1136/gutjnl-2012-303557

29. Park A, Kim WK, Bae KH. Distinction of white, beige and brown adipocytes derived from mesenchymal stem cells. World J Stem Cells (2014) 6(1):33-42. doi:10.4252/wjsc.v6.i1.33 
30. Rosenwald M, Wolfrum C. The origin and definition of brite versus white and classical brown adipocytes. Adipocyte (2014) 3(1):4-9. doi:10.4161/ adip. 26232

31. Giordano A, Smorlesi A, Frontini A, Barbatelli G, Cinti S. White, brown and pink adipocytes: the extraordinary plasticity of the adipose organ. Eur J Endocrinol (2014) 170(5):R159-71. doi:10.1530/EJE-13-0945

32. Rosen ED, Spiegelman BM. What we talk about when we talk about fat. Cell (2014) 156(1-2):20-44. doi:10.1016/j.cell.2013.12.012

33. Skurk T, Alberti-Huber C, Herder C, Hauner H. Relationship between adipocyte size and adipokine expression and secretion. J Clin Endocrinol Metab (2007) 92(3):1023-33. doi:10.1210/jc.2006-1055

34. Arner P. Human fat cell lipolysis: biochemistry, regulation and clinical role. Best Pract Res Clin Endocrinol Metab (2005) 19(4):471-82. doi:10.1016/j.beem. 2005.07.004

35. Zulian A, Cancello R, Micheletto G, Gentilini D, Gilardini L, Danelli P, et al. Visceral adipocytes: old actors in obesity and new protagonists in Crohn's disease? Gut (2012) 61(1):86-94. doi:10.1136/gutjnl-2011-300391

36. Kopp A, Buechler C, Bala M, Neumeier M, Scholmerich J, Schaffler A. Tolllike receptor ligands cause proinflammatory and prodiabetic activation of adipocytes via phosphorylation of extracellular signal-regulated kinase and c-Jun N-terminal kinase but not interferon regulatory factor-3. Endocrinology (2010) 151(3):1097-108. doi:10.1210/en.2009-1140

37. Weber M, Sporrer D, Weigert J, Wanninger J, Neumeier M, Wurm S, et al. Adiponectin downregulates galectin-3 whose cellular form is elevated whereas its soluble form is reduced in type 2 diabetic monocytes. FEBS Lett (2009) 583(22):3718-24. doi:10.1016/j.febslet.2009.10.008

38. Batra A, Zeitz M, Siegmund B. Adipokine signaling in inflammatory bowel disease. Inflamm Bowel Dis (2009) 15(12):1897-905. doi:10.1002/ibd. 20937

39. Mustain WC, Starr ME, Valentino JD, Cohen DA, Okamura D, Wang C, et al. Inflammatory cytokine gene expression in mesenteric adipose tissue during acute experimental colitis. PLoS One (2013) 8(12):e83693. doi:10.1371/journal. pone. 0083693

40. Thomaz MA, Acedo SC, de Oliveira CC, Pereira JA, Priolli DG, Saad MJ, et al. Methotrexate is effective in reactivated colitis and reduces inflammatory alterations in mesenteric adipose tissue during intestinal inflammation. Pharmacol Res (2009) 60(4):341-6. doi:10.1016/j.phrs.2009.05.003

41. Gambero A, Marostica M, Abdalla Saad MJ, Pedrazzoli J Jr. Mesenteric adipose tissue alterations resulting from experimental reactivated colitis. Inflamm Bowel Dis (2007) 13(11):1357-64. doi:10.1002/ibd.20222

42. Olivier I, Theodorou V, Valet P, Castan-Laurell I, Guillou H, Bertrand-Michel J, et al. Is Crohn's creeping fat an adipose tissue? Inflamm Bowel Dis (2011) 17(3):747-57. doi:10.1002/ibd.21413

43. Olivier I, Theodorou V, Valet P, Castan-Laurell I, Ferrier L, Eutamene H. Modifications of mesenteric adipose tissue during moderate experimental colitis in mice. Life Sci (2014) 94(1):1-7. doi:10.1016/j.lfs.2013.09.028

44. Gimble JM, Bunnell BA, Frazier T, Rowan B, Shah F, Thomas-Porch C, et al. Adipose-derived stromal/stem cells: a primer. Organogenesis (2013) 9(1):3-10. doi:10.4161/org.24279

45. Mantovani A, Locati M. Orchestration of macrophage polarization. Blood (2009) 114(15):3135-6. doi:10.1182/blood-2009-07-231795

46. Martinez FO, Sica A, Mantovani A, Locati M. Macrophage activation and polarization. Front Biosci (2008) 13:453-61. doi:10.2741/2692

47. Ginhoux F, Jung S. Monocytes and macrophages: developmental pathways and tissue homeostasis. Nat Rev Immunol (2014) 14(6):392-404. doi:10.1038/ nri3671

48. Morris DL, Singer K, Lumeng CN. Adipose tissue macrophages: phenotypic plasticity and diversity in lean and obese states. Curr Opin Clin Nutr Metab Care (2011) 14(4):341-6. doi:10.1097/MCO.0b013e328347970b

49. Lumeng CN, Bodzin JL, Saltiel AR. Obesity induces a phenotypic switch in adipose tissue macrophage polarization. J Clin Invest (2007) 117(1):175-84. doi:10.1172/JCI29881

50. Zeyda M, Farmer D, Todoric J, Aszmann O, Speiser M, Gyori G, et al. Human adipose tissue macrophages are of an anti-inflammatory phenotype but capable of excessive pro-inflammatory mediator production. Int J Obes (Lond) (2007) 31(9):1420-8. doi:10.1038/sj.ijo.0803632

51. Zeyda M, Stulnig TM. Adipose tissue macrophages. Immunol Lett (2007) 112(2):61-7. doi:10.1016/j.imlet.2007.07.003
52. Weisberg SP, McCann D, Desai M, Rosenbaum M, Leibel RL, Ferrante AW Jr. Obesity is associated with macrophage accumulation in adipose tissue. J Clin Invest (2003) 112(12):1796-808. doi:10.1172/JCI19246

53. Xu H, Barnes GT, Yang Q, Tan G, Yang D, Chou CJ, et al. Chronic inflammation in fat plays a crucial role in the development of obesity-related insulin resistance. J Clin Invest (2003) 112(12):1821-30. doi:10.1172/JCI19451

54. Olefsky JM, Glass CK. Macrophages, inflammation, and insulin resistance. Annu Rev Physiol (2010) 72:219-46. doi:10.1146/annurev-physiol-021909135846

55. Fain JN. Release of inflammatory mediators by human adipose tissue is enhanced in obesity and primarily by the nonfat cells: a review. Mediators Inflamm (2010) 2010:513948. doi:10.1155/2010/513948

56. Fain JN, Bahouth SW, Madan AK. TNFalpha release by the nonfat cells of human adipose tissue. Int J Obes Relat Metab Disord (2004) 28(4):616-22. doi:10.1038/sj.ijo.0802594

57. Cancello R, Henegar C, Viguerie N, Taleb S, Poitou C, Rouault C, et al. Reduction of macrophage infiltration and chemoattractant gene expression changes in white adipose tissue of morbidly obese subjects after surgery-induced weight loss. Diabetes (2005) 54(8):2277-86. doi:10.2337/diabetes.54.8.2277

58. Cancello R, Tordjman J, Poitou C, Guilhem G, Bouillot JL, Hugol D, et al. Increased infiltration of macrophages in omental adipose tissue is associated with marked hepatic lesions in morbid human obesity. Diabetes (2006) 55(6):1554-61. doi:10.2337/db06-0133

59. Chawla A, Nguyen KD, Goh YP. Macrophage-mediated inflammation in metabolic disease. Nat Rev Immunol (2011) 11(11):738-49. doi:10.1038/nri3071

60. Neels JG, Olefsky JM. Inflamed fat: what starts the fire? J Clin Invest (2006) 116(1):33-5. doi:10.1172/JCI27280

61. Carvalheira JB, Qiu Y, Chawla A. Blood spotlight on leukocytes and obesity. Blood (2013) 122(19):3263-7. doi:10.1182/blood-2013-04-459446

62. Shoelson SE, Lee J, Goldfine AB. Inflammation and insulin resistance. J Clin Invest (2006) 116(7):1793-801. doi:10.1172/JCI29069

63. Kim CS, Park HS, Kawada T, Kim JH, Lim D, Hubbard NE, et al. Circulating levels of MCP-1 and IL-8 are elevated in human obese subjects and associated with obesity-related parameters. Int J Obes (Lond) (2006) 30(9):1347-55. doi:10.1038/sj.ijo.0803259

64. Inouye KE, Shi H, Howard JK, Daly CH, Lord GM, Rollins BJ, et al. Absence of CC chemokine ligand 2 does not limit obesity-associated infiltration of macrophages into adipose tissue. Diabetes (2007) 56(9):2242-50. doi:10.2337/ db07-0425

65. Weisberg SP, Hunter D, Huber R, Lemieux J, Slaymaker S, Vaddi K, et al. CCR2 modulates inflammatory and metabolic effects of high-fat feeding. J Clin Invest (2006) 116(1):115-24. doi:10.1172/JCI24335C1

66. Kitade H, Sawamoto K, Nagashimada M, Inoue H, Yamamoto Y, Sai Y, et al. CCR5 plays a critical role in obesity-induced adipose tissue inflammation and insulin resistance by regulating both macrophage recruitment and M1/M2 status. Diabetes (2012) 61(7):1680-90. doi:10.2337/db11-1506

67. Kim D, Kim J, Yoon JH, Ghim J, Yea K, Song P, et al. CXCL12 secreted from adipose tissue recruits macrophages and induces insulin resistance in mice. Diabetologia (2014) 57(7):1456-65. doi:10.1007/s00125-014-3237-5

68. Nagareddy PR, Kraakman M, Masters SL, Stirzaker RA, Gorman DJ, Grant RW, et al. Adipose tissue macrophages promote myelopoiesis and monocytosis in obesity. Cell Metab (2014) 19(5):821-35. doi:10.1016/j.cmet.2014.03.029

69. Trayhurn P. Hypoxia and adipose tissue function and dysfunction in obesity. Physiol Rev (2013) 93(1):1-21. doi:10.1152/physrev.00017.2012

70. Dalmas E, Clement K, Guerre-Millo M. Defining macrophage phenotype and function in adipose tissue. Trends Immunol (2011) 32(7):307-14. doi:10.1016/ j.it.2011.04.008

71. Jenkins SJ, Ruckerl D, Cook PC, Jones LH, Finkelman FD, van Rooijen $\mathrm{N}$, et al. Local macrophage proliferation, rather than recruitment from the blood, is a signature of TH2 inflammation. Science (2011) 332(6035):1284-8. doi:10.1126/science. 1204351

72. Haase J, Weyer U, Immig K, Kloting N, Bluher M, Eilers J, et al. Local proliferation of macrophages in adipose tissue during obesity-induced inflammation. Diabetologia (2014) 57(3):562-71. doi:10.1007/s00125-013-3139-y

73. Amano SU, Cohen JL, Vangala P, Tencerova M, Nicoloro SM, Yawe JC, et al. Local proliferation of macrophages contributes to obesity-associated adipose tissue inflammation. Cell Metab (2014) 19(1):162-71. doi:10.1016/j.cmet. 2013.11.017 
74. Oh HJ, Park EJ, Lee SY, Soh JW, Kong IS, Choi SW, et al. Comparison of cell proliferation and epigenetic modification of gene expression patterns in canine foetal fibroblasts and adipose tissue-derived mesenchymal stem cells. Cell Prolif (2012) 45(5):438-44. doi:10.1111/j.1365-2184.2012.00838.x

75. Lumeng CN, DelProposto JB, Westcott DJ, Saltiel AR. Phenotypic switching of adipose tissue macrophages with obesity is generated by spatiotemporal differences in macrophage subtypes. Diabetes (2008) 57(12):3239-46. doi:10.2337/db08-0872

76. Cinti S, Mitchell G, Barbatelli G, Murano I, Ceresi E, Faloia E, et al. Adipocyte death defines macrophage localization and function in adipose tissue of obese mice and humans. J Lipid Res (2005) 46(11):2347-55. doi:10.1194/jlr. M500294-JLR200

77. Aron-Wisnewsky J, Tordjman J, Poitou C, Darakhshan F, Hugol D, Basdevant $\mathrm{A}$, et al. Human adipose tissue macrophages: $\mathrm{m} 1$ and $\mathrm{m} 2$ cell surface markers in subcutaneous and omental depots and after weight loss. J Clin Endocrinol Metab (2009) 94(11):4619-23. doi:10.1210/jc.2009-0925

78. Clement K, Viguerie N, Poitou C, Carette C, Pelloux V, Curat CA, et al. Weight loss regulates inflammation-related genes in white adipose tissue of obese subjects. FASEB J (2004) 18(14):1657-69. doi:10.1096/fj.04-2204com

79. Spencer M, Yao-Borengasser A, Unal R, Rasouli N, Gurley CM, Zhu B, et al. Adipose tissue macrophages in insulin-resistant subjects are associated with collagen VI and fibrosis and demonstrate alternative activation. Am J Physiol Endocrinol Metab (2010) 299(6):E1016-27. doi:10.1152/ajpendo.00329.2010

80. Fjeldborg K, Pedersen SB, Moller HJ, Christiansen T, Bennetzen M, Richelsen B. Human adipose tissue macrophages are enhanced but changed to an anti-inflammatory profile in obesity. J Immunol Res (2014) 2014:309548. doi:10.1155/2014/309548

81. Wentworth JM, Naselli G, Brown WA, Doyle L, Phipson B, Smyth GK, et al. Pro-inflammatory CD11c+CD206+ adipose tissue macrophages are associated with insulin resistance in human obesity. Diabetes (2010) 59(7):1648-56. doi:10.2337/db09-0287

82. Kredel LI, Batra A, Stroh T, Kuhl AA, Zeitz M, Erben U, et al. Adipokines from local fat cells shape the macrophage compartment of the creeping fat in Crohn's disease. Gut (2012) 62(6):852-62. doi:10.1136/gutjnl-2011-301424

83. Lovren F, Pan Y, Quan A, Szmitko PE, Singh KK, Shukla PC, et al. Adiponectin primes human monocytes into alternative anti-inflammatory M2 macrophages. Am J Physiol Heart Circ Physiol (2010) 299(3):H656-63. doi:10.1152/ajpheart.00115.2010

84. Wu D, Molofsky AB, Liang HE, Ricardo-Gonzalez RR, Jouihan HA, Bando JK, et al. Eosinophils sustain adipose alternatively activated macrophages associated with glucose homeostasis. Science (2011) 332(6026):243-7. doi:10.1126/ science. 1201475

85. Kang K, Reilly SM, Karabacak V, Gangl MR, Fitzgerald K, Hatano B, et al. Adipocyte-derived Th2 cytokines and myeloid PPARdelta regulate macrophage polarization and insulin sensitivity. Cell Metab (2008) 7(6):485-95. doi:10. 1016/j.cmet.2008.04.002

86. Lee SD, Tontonoz P. Eosinophils in fat: pink is the new brown. Cell (2014) 157(6):1249-50. doi:10.1016/j.cell.2014.05.025

87. Talukdar S, Oh da Y, Bandyopadhyay G, Li D, Xu J, McNelis J, et al. Neutrophils mediate insulin resistance in mice fed a high-fat diet through secreted elastase. Nat Med (2012) 18(9):1407-12. doi:10.1038/nm.2885

88. Hams E, Locksley RM, McKenzie AN, Fallon PG. Cutting edge: IL-25 elicits innate lymphoid type 2 and type II NKT cells that regulate obesity in mice. J Immunol (2013) 191(11):5349-53. doi:10.4049/jimmunol.1301176

89. Molofsky AB, Nussbaum JC, Liang HE, Van Dyken SJ, Cheng LE, Mohapatra A, et al. Innate lymphoid type 2 cells sustain visceral adipose tissue eosinophils and alternatively activated macrophages. J Exp Med (2013) 210(3):535-49. doi:10.1084/jem.20121964

90. Walker JA, Barlow JL, McKenzie AN. Innate lymphoid cells - how did we miss them? Nat Rev Immunol (2013) 13(2):75-87. doi:10.1038/nri3349

91. Lanier LL. Shades of grey - the blurring view of innate and adaptive immunity. Nat Rev Immunol (2013) 13(2):73-4. doi:10.1038/nri3389

92. Bernink J, Mjosberg J, Spits H. Th1- and Th2-like subsets of innate lymphoid cells. Immunol Rev (2013) 252(1):133-8. doi:10.1111/imr.12034

93. Spits H. Group 2 innate lymphoid cells show up in the skin. Immunol Cell Biol (2013) 91(6):390-2. doi:10.1038/icb.2013.24

94. Spits H, Artis D, Colonna M, Diefenbach A, Di Santo JP, Eberl G, et al. Innate lymphoid cells - a proposal for uniform nomenclature. Nat Rev Immunol (2013) 13(2):145-9. doi:10.1038/nri3365
95. Ferlazzo G, Thomas D, Lin SL, Goodman K, Morandi B, Muller WA, et al. The abundant NK cells in human secondary lymphoid tissues require activation to express killer cell Ig-like receptors and become cytolytic. J Immunol (2004) 172(3):1455-62. doi:10.4049/jimmunol.172.3.1455

96. Basu S, Eriksson M, Pioli PA, Conejo-Garcia J, Mselle TF, Yamamoto S, et al. Human uterine NK cells interact with uterine macrophages via NKG2D upon stimulation with PAMPs. Am J Reprod Immunol (2009) 61(1):52-61. doi:10.1111/j.1600-0897.2008.00661.x

97. Duffaut C, Galitzky J, Lafontan M, Bouloumie A. Unexpected trafficking of immune cells within the adipose tissue during the onset of obesity. Biochem Biophys Res Commun (2009) 384(4):482-5. doi:10.1016/j.bbrc.2009.05.002

98. O’Rourke RW, Gaston GD, Meyer KA, White AE, Marks DL. Adipose tissue NK cells manifest an activated phenotype in human obesity. Metabolism (2013) 62(11):1557-61. doi:10.1016/j.metabol.2013.07.011

99. Lynch L. Adipose invariant natural killer T cells. Immunology (2014) 142(3):337-46. doi:10.1111/imm.12269

100. Watarai H, Sekine-Kondo E, Shigeura T, Motomura Y, Yasuda T, Satoh R, et al. Development and function of invariant natural killer $\mathrm{T}$ cells producing $\mathrm{T}(\mathrm{h}) 2$ and T(h)17-cytokines. PLoS Biol (2012) 10(2):e1001255. doi:10.1371/journal. pbio. 1001255

101. Brennan PJ, Brigl M, Brenner MB. Invariant natural killer T cells: an innate activation scheme linked to diverse effector functions. Nat Rev Immunol (2013) 13(2):101-17. doi:10.1038/nri3369

102. Lynch L, Nowak M, Varghese B, Clark J, Hogan AE, Toxavidis V, et al. Adipose tissue invariant NKT cells protect against diet-induced obesity and metabolic disorder through regulatory cytokine production. Immunity (2012) 37(3):574-87. doi:10.1016/j.immuni.2012.06.016

103. Schipper HS, Rakhshandehroo M, van de Graaf SF, Venken K, Koppen A, Stienstra R, et al. Natural killer $\mathrm{T}$ cells in adipose tissue prevent insulin resistance. J Clin Invest (2012) 122(9):3343-54. doi:10.1172/JCI62739

104. Schipper HS, Prakken B, Kalkhoven E, Boes M. Adipose tissue-resident immune cells: key players in immunometabolism. Trends Endocrinol Metab (2012) 23(8):407-15. doi:10.1016/j.tem.2012.05.011

105. Ji YS, Xu A, Bhargava P, Yang L, Lam KS, Gao B, et al. Activation of natural killer T'cells promotes M2 Macrophage polarization in adipose tissue and improves systemic glucose tolerance via -4 (IL-4)/STAT6 protein signaling axis in obesity. J Biol Chem (2012) 287(17):13561-71. doi:10.1074/jbc.M112. 350066

106. Ji YS, Xia S, Yang L, Li X, Qi L. Short term high fat diet challenge promotes alternative macrophage polarization in adipose tissue via natural killer T cells and interleukin-42012. J Biol Chem (2012) 287(29):24378-86. doi:10.1074/jbc.M112.371807

107. Martin-Murphy BV, You Q, Wang H, De La Houssaye BA, Reilly TP, Friedman JE, et al. Mice lacking natural killer T cells are more susceptible to metabolic alterations following high fat diet feeding. PLoS One (2014) 9(1):e80949. doi:10.1371/journal.pone.0080949

108. Feuerer M, Herrero L, Cipolletta D, Naaz A, Wong J, Nayer A, et al. Lean, but not obese, fat is enriched for a unique population of regulatory $\mathrm{T}$ cells that affect metabolic parameters. Nat Med (2009) 15(8):930-9. doi:10.1038/ nm.2002

109. Duffaut C, Zakaroff-Girard A, Bourlier V, Decaunes P, Maumus M, Chiotasso $\mathrm{P}$, et al. Interplay between human adipocytes and $\mathrm{T}$ lymphocytes in obesity: CCL20 as an adipochemokine and T lymphocytes as lipogenic modulators. Arterioscler Thromb Vasc Biol (2009) 29(10):1608-14. doi:10.1161/ATVBAHA. 109.192583

110. O'Rourke RW, Metcalf MD, White AE, Madala A, Winters BR, Maizlin II, et al. Depot-specific differences in inflammatory mediators and a role for NK cells and IFN-gamma in inflammation in human adipose tissue. Int J Obes (Lond) (2009) 33(9):978-90. doi:10.1038/ijo.2009.133

111. Wu H, Ghosh S, Perrard XD, Feng L, Garcia GE, Perrard JL, et al. T-cell accumulation and regulated on activation, normal $\mathrm{T}$ cell expressed and secreted upregulation in adipose tissue in obesity. Circulation (2007) 115(8):1029-38. doi:10.1161/CIRCULATIONAHA.106.638379

112. Winer S, Chan Y, Paltser G, Truong D, Tsui H, Bahrami J, et al. Normalization of obesity-associated insulin resistance through immunotherapy. Nat Med (2009) 15(8):921-9. doi:10.1038/nm.2001

113. Feuerer M, Hill JA, Mathis D, Benoist C. Foxp3+ regulatory T cells: differentiation, specification, subphenotypes. Nat Immunol (2009) 10(7):689-95 doi:10.1038/ni.1760 
114. Cipolletta D. Adipose tissue-resident regulatory T cells: phenotypic specialization, functions and therapeutic potential. Immunology (2014) 142(4):517-25. doi:10.1111/imm.12262

115. Cipolletta D, Feuerer M, Li A, Kamei N, Lee J, Shoelson SE, et al. PPAR-gamma is a major driver of the accumulation and phenotype of adipose tissue Treg cells. Nature (2012) 486(7404):549-53. doi:10.1038/nature11132

116. Cipolletta D, Kolodin D, Benoist C, Mathis D. Tissular T(regs): a unique population of adipose-tissue-resident Foxp3+CD4+ T cells that impacts organismal metabolism. Semin Immunol (2011) 23(6):431-7. doi:10.1016/j.smim. 2011.06.002

117. Ilan Y, Maron R, Tukpah AM, Maioli TU, Murugaiyan G, Yang K, et al. Induction of regulatory $\mathrm{T}$ cells decreases adipose inflammation and alleviates insulin resistance in ob/ob mice. Proc Natl Acad Sci U S A (2010) 107(21):9765-70. doi:10.1073/pnas.0908771107

118. Zeyda M, Huber J, Prager G, Stulnig TM. Inflammation correlates with markers of $\mathrm{T}$-cell subsets including regulatory $\mathrm{T}$ cells in adipose tissue from obese patients. Obesity (Silver Spring) (2010) 19(4):743-8. doi:10.1038/oby. 2010.123

119. Geremia A, Biancheri P, Allan P, Corazza GR, Di Sabatino A. Innate and adaptive immunity in inflammatory bowel disease. Autoimmun Rev (2014) 13(1):3-10. doi:10.1016/j.autrev.2013.06.004

120. Maul J, Loddenkemper C, Mundt P, Berg E, Giese T, Stallmach A, et al. Peripheral and intestinal regulatory CD4+ CD25(high) $\mathrm{T}$ cells in inflammatory bowel disease. Gastroenterology (2005) 128(7):1868-78. doi:10.1053/j.gastro. 2005.03.043

121. Wang Y, Liu XP, Zhao ZB, Chen JH, Yu CG. Expression of CD4+ forkhead box P3 (FOXP3)+ regulatory T cells in inflammatory bowel disease. J Dig Dis (2011) 12(4):286-94. doi:10.1111/j.1751-2980.2011.00505.x

122. Lee YK, Mukasa R, Hatton RD, Weaver CT. Developmental plasticity of Th17 and Treg cells. Curr Opin Immunol (2009) 21(3):274-80. doi:10.1016/j.coi. 2009.05.021

123. Rovedatti L, Kudo T, Biancheri P, Sarra M, Knowles CH, Rampton DS, et al. Differential regulation of -17 and interferon gamma production in inflammatory bowel disease. Gut (2009) 58(12):1629-36. doi:10.1136/gut.2009.182170

124. Ding S, Chi MM, Scull BP, Rigby R, Schwerbrock NM, Magness S, et al. Highfat diet: bacteria interactions promote intestinal inflammation which precedes and correlates with obesity and insulin resistance in mouse. PLoS One (2010) 5(8):e12191. doi:10.1371/journal.pone.0012191

125. Lam YY, Ha CW, Campbell CR, Mitchell AJ, Dinudom A, Oscarsson J, et al. Increased gut permeability and microbiota change associate with mesenteric fat inflammation and metabolic dysfunction in diet-induced obese mice. PLoS One (2012) 7(3):e34233. doi:10.1371/journal.pone.0034233

126. Brun P, Castagliuolo I, Di Leo V, Buda A, Pinzani M, Palu G, et al. Increased intestinal permeability in obese mice: new evidence in the pathogenesis of nonalcoholic steatohepatitis. Am J Physiol Gastrointest Liver Physiol (2007) 292(2):G518-25. doi:10.1152/ajpgi.00024.2006

127. Ungar B, Kopylov U, Goitein D, Lahat A, Bardan E, Avidan B, et al. Severe and morbid obesity in Crohn's disease patients: prevalence and disease associations. Digestion (2013) 88(1):26-32. doi:10.1159/000351529

128. Mendall MA, Gunasekera AV, John BJ, Kumar D. Is obesity a risk factor for Crohn's disease? Dig Dis Sci (2011) 56(3):837-44. doi:10.1007/s10620-0101541-6

129. Max JB, Stidham R, Su GL, Waljee AK. Obesity and IBD: are we tipping the scales toward an epidemic? Gastroenterology (2013) 145(2):478-9. doi:10.1053/j.gastro.2013.06.020

130. Blain A, Cattan S, Beaugerie L, Carbonnel F, Gendre JP, Cosnes J. Crohn's disease clinical course and severity in obese patients. Clin Nutr (2002) 21(1):51-7. doi:10.1054/clnu.2001.0503

131. Nascimento AT, Rocha R, Coqueiro FG, Santana GO, Lyra AC. Does obesity complicate inflammatory bowel diseases? J Crohns Colitis (2014) 6(10):1041. doi:10.1016/j.crohns.2012.06.008

132. Hass DJ, Brensinger CM, Lewis JD, Lichtenstein GR. The impact of increased body mass index on the clinical course of Crohn's disease. Clin Gastroenterol Hepatol (2006) 4(4):482-8. doi:10.1016/j.cgh.2005.12.015

133. Causey MW, Johnson EK, Miller S, Martin M, Maykel J, Steele SR. The impact of obesity on outcomes following major surgery for Crohn's disease: an American College of Surgeons National Surgical Quality Improvement Program assessment. Dis Colon Rectum (2011) 54(12):1488-95. doi:10.1097/DCR. 0b013e3182342ccb
134. Long MD, Crandall WV, Leibowitz IH, Duffy L, del Rosario F, Kim SC, et al. Prevalence and epidemiology of overweight and obesity in children with inflammatory bowel disease. Inflamm Bowel Dis (2011) 17(10):2162-8. doi:10.1002/ibd.21585

135. Zwintscher NP, Horton JD, Steele SR. Obesity has minimal impact on clinical outcomes in children with inflammatory bowel disease. J Pediatr Surg (2014) 49(2):265-8; discussion 8. doi:10.1016/j.jpedsurg.2013.11.033

136. Bhalme MS, Sharma A, Keld R, Willert R, Campbell S. Does weight-adjusted anti-tumour necrosis factor treatment favour obese patients with Crohn's disease? Eur J Gastroenterol Hepatol (2013) 25(5):543-9. doi:10.1097/MEG. 0b013e32835d1f15

137. Harper JW, Sinanan MN, Zisman TL. Increased body mass index is associated with earlier time to loss of response to infliximab in patients with inflammatory bowel disease. Inflamm Bowel Dis (2013) 19(10):2118-24. doi:10.1097/MIB.0b013e31829cf401

138. Gremese E, Bernardi S, Bonazza S, Nowik M, Peluso G, Massara A, et al. Body weight, gender and response to TNF-alpha blockers in axial spondyloarthritis. Rheumatology (Oxford) (2014) 53(5):875-81. doi:10.1093/rheumatology/ ket433

139. Hou JK, Abraham B, El-Serag H. Dietary intake and risk of developing inflammatory bowel disease: a systematic review of the literature. Am J Gastroenterol (2011) 106(4):563-73. doi:10.1038/ajg.2011.44

140. Gruber L, Kisling S, Lichti P, Martin FP, May S, Klingenspor M, et al. High fat diet accelerates pathogenesis of murine Crohn's disease-like ileitis independently of obesity. PLoS One (2013) 8(8):e71661. doi:10.1371/journal.pone. 0071661

141. Devkota S, Wang Y, Musch MW, Leone V, Fehlner-Peach H, Nadimpalli A, et al. Dietary-fat-induced taurocholic acid promotes pathobiont expansion and colitis in Il10-/- mice. Nature (2012) 487(7405):104-8. doi:10.1038/ nature 11225

142. Wajchenberg BL. Subcutaneous and visceral adipose tissue: their relation to the metabolic syndrome. Endocr Rev (2000) 21(6):697-738. doi:10.1210/edrv. 21.6.0415

143. Lee M-J, Fried SK. Depot-specific biology of adipose tissues: links to fat distribution and metabolic risk. In: Leff T, Granneman JG, editors. Adipose Tissue in Health and Disease. Weinheim: Wiley-VCH Verlag GmbH \& Co (2010). p. 283-306.

144. Patel P, Abate N. Body fat distribution and insulin resistance. Nutrients (2013) 5(6):2019-27. doi:10.3390/nu5062019

145. Berryman DE, Glad CA, List EO, Johannsson G. The GH/IGF-1 axis in obesity: pathophysiology and therapeutic considerations. Nat Rev Immunol (2013) 9(6):346-56. doi:10.1038/nrendo.2013.64

146. Motoshima H, Wu X, Sinha MK, Hardy VE, Rosato EL, Barbot DJ, et al. Differential regulation of adiponectin secretion from cultured human omental and subcutaneous adipocytes: effects of insulin and rosiglitazone. J Clin Endocrinol Metab (2002) 87(12):5662-7. doi:10.1210/jc.2002-020635

147. Freedland ES. Role of a critical visceral adipose tissue threshold (CVATT) in metabolic syndrome: implications for controlling dietary carbohydrates: a review. Nutr Metab (2004) 1(1):12. doi:10.1186/1743-7075-1-12

148. Dusserre E, Moulin P, Vidal H. Differences in mRNA expression of the proteins secreted by the adipocytes in human subcutaneous and visceral adipose tissues. Biochim Biophys Acta (2000) 1500(1):88-96. doi:10.1016/S0925-4439(99) 00091-5

149. Pou KM, Massaro JM, Hoffmann U, Vasan RS, Maurovich-Horvat P, Larson $\mathrm{MG}$, et al. Visceral and subcutaneous adipose tissue volumes are crosssectionally related to markers of inflammation and oxidative stress: the Framingham Heart Study. Circulation (2007) 116(11):1234-41. doi:10.1161/ CIRCULATIONAHA.107.710509

150. Karlsson C, Lindell K, Ottosson M, Sjostrom L, Carlsson B, Carlsson LM. Human adipose tissue expresses angiotensinogen and enzymes required for its conversion to angiotensin II. J Clin Endocrinol Metab (1998) 83(11):3925-9. doi:10.1210/jc.83.11.3925

151. Bruun JM, Lihn AS, Pedersen SB, Richelsen B. Monocyte chemoattractant protein-1 release is higher in visceral than subcutaneous human adipose tissue (AT): implication of macrophages resident in the AT. J Clin Endocrinol Metab (2005) 90(4):2282-9. doi:10.1210/jc.2004-1696

152. Ibrahim MM. Subcutaneous and visceral adipose tissue: structural and functional differences. Obes Rev (2010) 11(1):11-8. doi:10.1111/j.1467-789X.2009. 00623.x 
153. Ferrer-Lorente R, Bejar MT, Badimon L. Notch signaling pathway activation in normal and hyperglycemic rats differs in the stem cells of visceral and subcutaneous adipose tissue. Stem Cells Dev (2014). doi:10.1089/scd.2014.0070

Conflict of Interest Statement: The authors declare that the research was conducted in the absence of any commercial or financial relationships that could be construed as a potential conflict of interest.

Received: 06 August 2014; accepted: 10 September 2014; published online: 24 September 2014
Citation: Kredel LI and Siegmund B (2014) Adipose-tissue and intestinal inflammation - visceral obesity and creeping fat. Front. Immunol. 5:462. doi: 10.3389/fimmu.2014.00462

This article was submitted to Inflammation, a section of the journal Frontiers in Immunology.

Copyright (C) 2014 Kredel and Siegmund. This is an open-access article distributed under the terms of the Creative Commons Attribution License (CC BY). The use, distribution or reproduction in other forums is permitted, provided the original author(s) or licensor are credited and that the original publication in this journal is cited, in accordance with accepted academic practice. No use, distribution or reproduction is permitted which does not comply with these terms. 